\title{
Integrert medisin i London
}

\author{
The Royal London Hospital for Integrated Medicine er det største offentlige sykehuset i Europa som \\ tilbyr alternativ behandling. Her har pasienter i mer enn 160 år fått tradisjonell medisinsk behandling \\ i kombinasjon med alternative metoder som for eksempel akupunktur, healing og homøopati.
}

\section{Arne Johan Norheim}

arne.johan.norheim@hlkbb.no

Nasjonalt forskningssenter innen komplementær og alternativ medisin (NAFKAM)

Universitetet i Tromsø

og

Vitalisklinikken

Rødbergveien 6

9408 Harstad

Sykehuset ble etablert i Soho i 1849 og om lag 10 år senere flyttet til sin nåværende beliggenhet i Great Ormond Street, Bloomsbury, i hjertet av London. I 1948 ble sykehuset anerkjent av det offentlige helsevesen
(National Health Service) som «teaching hospital», i 1982 underlagt offentlig helseadministrasjon, mens det i 2002 ble en integrert del av The University College London Hospitals (1). I 2010 ble navnet endret fra Royal London Homoeopathic Hospital til The Royal London Hospital for Integrated Medicine (RLHIM) for bedre å reflektere aktiviteten ved sykehuset (2). Gjennom min tilknytning til Nasjonalt forskningssenter innen komplementær og alternativ medisin (NAFKAM) besøkte jeg sykehuset høsten 2010.

\section{Krav om helsefaglig utdanning}

Pasientbehandlingen foregår på poliklinikker som ledes av leger med spesialistutdanning, oftest innen allmennmedisin, men også indremedisin og pediatri. Alle ansatte med pasientkontakt skal ha helsefaglig utdanning med offentlig godkjenning (3).

Sykehuset samarbeider tett med andre samlokaliserte universitetssykehus om pasientbehandlingen. Det alternativmedisinske sykehuset har dermed tilgang til moderne konvensjonelle undersøkelsesteknikker og innleggelse (3). Tilsvarende kan andre sykehus henvise pasienter hit når alternativ behandling er indisert.

Noen av de viktigste kliniske arbeidsområdene omfatter kvinnehelse, komplementær kreftomsorg, dermatologi, revmatologi, pediatri samt utredning og behandling av allergi. På sykehuset finnes også selv-

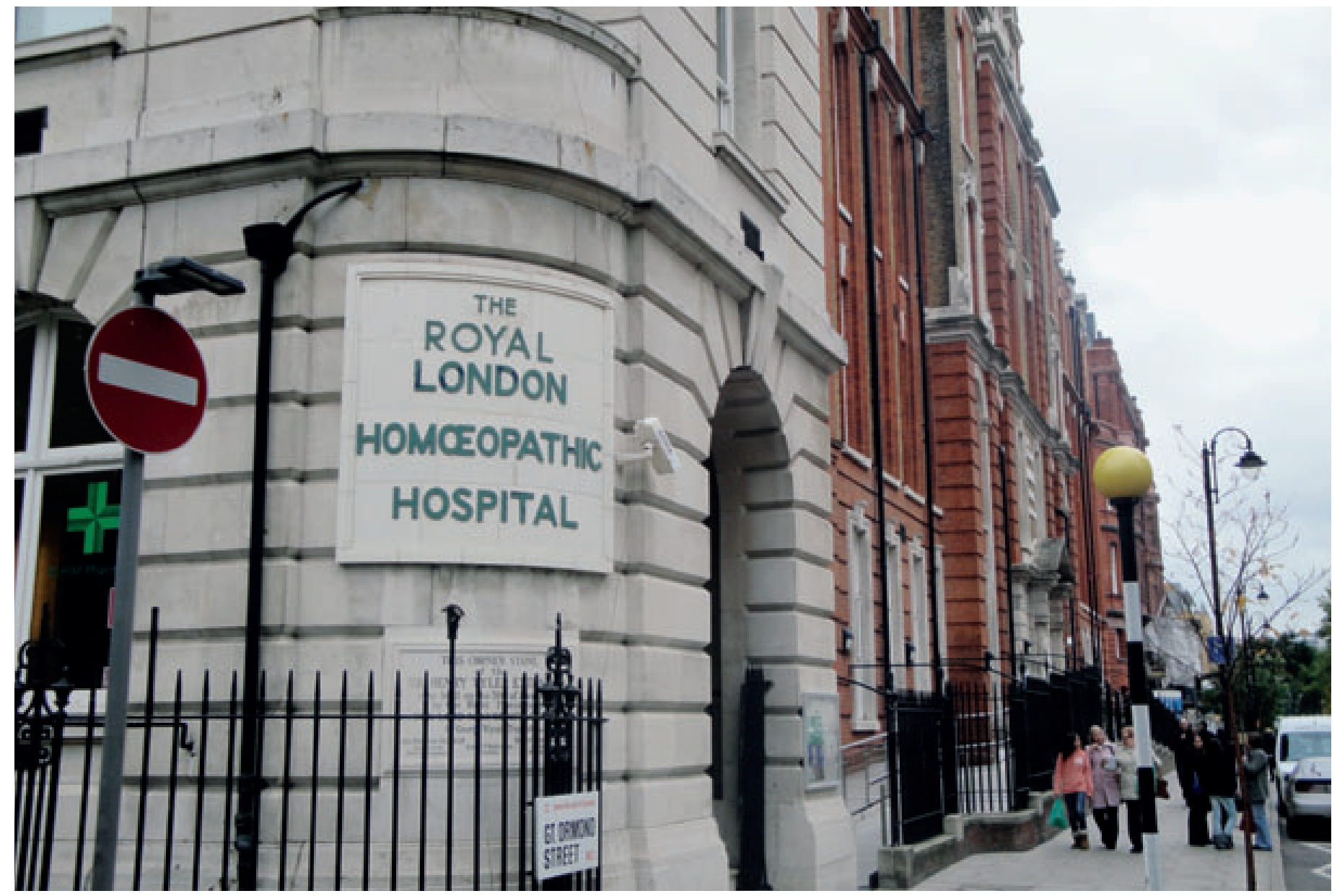

The Royal London Hospital for Integrated Medicine før det byttet navn i 2010. Foto Arne Johan Norheim 
stendige klinikker for stress, stemningslidelser og kronisk utmattelsessyndrom.

Det er ingen tvil om at sykehuset har en tung historie i forhold til alternativ behandling på sykehus. Imidlertid er mye av miljøet i sykehuset forandret: kontorene er blitt stadig mindre og den gamle arkitekturen er byttet ut med moderne stilarter. Noen leger ved sykehuset gir uttrykk for at det ikke bare er fordeler med å være del av et universitetsmiljø og underlagt krav og forventninger som omfatter offentlig helsetjeneste.

Stramme budsjettrammer, behandlingsgaranti og effektivitetskrav oppleves som en trussel mot et godt behandlingsmiljø. For eksempel finnes gruppebehandling der 6-8 pasienter får akupunktur samtidig, kun atskilt av forheng. Akupunktøren er innom en kort stund for å sette nåler, og i løpet av en hektisk formiddag er 20-25 pasienter blitt nålebehandlet.

\section{Eget apotek}

Sykehusapoteket, som også er ordinært apotek for pasienter med resepter utstedt utenfor sykehuset, drives av farmasøyter innen ordinær farmakologi. Flere av farmasøytene har tilleggsutdanning innen én eller flere alternative behandlingsformer og vestlig urtemedisin. Foruten ordinære medikamenter har sykehuset et omfattende tilbud av homøopatiske preparater. En rekke urteekstrakter og naturmedisiner blir også produsert, blandet og tilberedt i apoteket, ofte forskrevet av legene ved sykehuset.

Utdanning, forskning og informasjon RLHIM er som universitetssykehus pålagt å undervise helsepersonell, og det under- vises i temaer innen både ordinær medisinsk og integrert behandling. Kursserien for allmennpraktikere er den eneste kursserien i integrert behandling i England.

Sykehuset har vært involvert i flere studier, særlig randomiserte kontrollerte studier innen akupunktur, og i utarbeiding av flere Cochrane-oversikter (4), epidemiologiske studier samt etiske vurderinger av forskning innen alternativ behandling. Det nasjonale informasjonssenteret for integrert behandling, Complementary and Alternative Medicine Library and Information Service (CAMLIS), er et lånebibliotek for alle medlemmer og ansatte ved universitetssykehuset (5).

\section{Hva med Norge?}

I Norge har vi ingen velorganisert offentlig poliklinisk praksis innen alternativ behandling. Likevel er for eksempel akupunktur i bruk ved flere av de norske sykehusene, og det synes for enkelte tilstander å være åpning for bruk også av andre alternative behandlingsformer (6).

Etter et besøk ved sykehuset i London vil jeg argumentere for at man bør reflektere enda en gang før man etablerer norske offentlige poliklinikker med tilbud om alternativ behandling på det offentlige helsevesenets premisser. Mange utøvere av alternativ medisin beskriver seg gjerne som mer holistisk, pasientsentrert og inkluderende sammenliknet med deler av moderne, effektiv sykehusmedisin. Videre er det diskutabelt om kunnskapsgrunnlaget tilsier at vi kan bruke sårt tiltrengte offentlige helsekroner på innføring av alternativ medisin i offentlig helsevesen i større omfang enn i dag.
Selvsagt kan en større integrering av alternativ behandling i det offentlige helsevesen være uttrykk for større grad av aksept, men kampen om offentlige midler og stadige omorganiseringer kan være uheldig for den alternative pasientbehandlingen. Dersom alternativ behandling gjennom fullstendig integrering mister «det alternative» ved seg, så kan selve integreringen påvirke utøvelsen av behandlingen - og dermed også kanskje noe av effekten?

Oppgitte interessekonflikter: Ingen

Litteratur

1. Wikipedia. Royal London Hospital for Integrated Medicine. http://en.wikipedia.org/wiki/ Royal_London_Hospital_for_Integrated_Medicine (10.12.2010).

2. University College London Hospitals NHS foundation trust. New landmark for integrated medicine. www.uclh.nhs.uk/news/pages/ newlandmarkforintegratedmedicine.aspx (10.12.2010).

3. University College London Hospitals NHS foundation trust. Our hospitals. www.uclh.nhs.uk/Pages/ home.aspx (10.12.2010)

4. Kassab S, Cummings M, Berkovitz S et al. Homeopathic medicines for adverse effects of cancer treatments. Cochrane Database Syst Rev 2009. nr. 2: CD004845.

5. Complementary and alternative medicine. Library and information service. www.cam.nhs.uk (10.12.2010).

6. Salomonsen LJ, Skovgaard L, la Cour S et al. Use of complementary and alternative treatment in Norwegian and Danish hospitals. BMC Complement Altern Med 2011; 11: 4

Mottatt 21.11. 2010, første revisjon innsendt 19.12. 2010, godkjent 24.2. 2011. Medisinsk redaktør Siri Lunde. 